\title{
Experimental investigation of dielectric properties of seasonal snow at field observatories in the northwest Himalaya
}

\author{
Kamal K. SINGH, ${ }^{1}$ Ashavani KUMAR, ${ }^{2}$ Anil V. KULKARNI, ${ }^{3}$ Prem DATT, ${ }^{1}$ \\ Sanjay K. DEWALI, ${ }^{1}$ Manoj KUMAR ${ }^{1}$ \\ ${ }^{1}$ Snow and Avalanche Study Establishment (SASE), Chandigarh, India \\ ${ }^{2}$ National Institute of Technology (NIT), Kurukshetra, India \\ ${ }^{3}$ Divecha Center for Climate Change, Indian Institute of Science, Bangalore, India \\ Correspondence: Kamal K. Singh <kamal.kant@sase.drdo.in>
}

\begin{abstract}
Radio-echo sounding techniques are very useful for fast profiling of seasonal snowpack. Ground-penetrating radar (GPR) is used widely for various cryospheric applications, such as snow/ glacier depth estimation, snow layer identification and snow water equivalent assessment. The dielectric constant of snow is an important input parameter for the acquisition and interpretation of GPR data from the snowpack. In this study, snow dielectric constant was measured along with physical properties of snow using a snow fork operating at $1 \mathrm{GHz}$ frequency. Experiments were conducted at field observatories of the Snow and Avalanche Study Establishment located in different Himalayan ranges: Patseo (Greater Himalayan range), Dhundhi and Solang (Pir Panjal range). Interseasonal spatial and temporal variations in snow dielectric constant and associated snowpack properties were analysed for five winter seasons (2010-14). The mean seasonal snow dielectric constant is higher at Dhundhi $(1.82 \pm 0.02)$ than at Patseo $(1.69 \pm 0.02)$. The measured snow dielectric constant was used to derive snow density and liquid-water content (LWC). A better correlation between snow dielectric constant and LWC is observed for high-density snow $\left(>300 \mathrm{~kg} \mathrm{~m}^{-3} ; R^{2}=0.95\right)$ than for low-density snow $\left(<200 \mathrm{~kg} \mathrm{~m}^{-3} ; R^{2}=0.73\right)$. Snow-fork-derived snow density was in good agreement with manually measured values. The snow dielectric constant database generated during this study can be used as a reference for various field applications of GPR in snow-related studies.
\end{abstract}

KEYWORDS: dielectric constant, ground-penetrating radar, liquid-water content, snow, snow fork

\section{INTRODUCTION}

Seasonal snow cover in the Indian Himalaya plays an important role in various cryospheric research processes of concern in climatology, glaciology, hydrology and avalanche studies. However, there is large spatial and temporal variability in snowpack properties (e.g. dielectric constant, density and moisture content) in different Himalayan ranges due to the varying climate and terrain. Ground-penetrating radar (GPR), a non-destructive radio-echo sounding technique, is used to collect point values as well as the spatial distribution of snow properties. Various snow properties, such as depth distribution, identification of internal layer structures, and onset of wetness (Machguth and others, 2006; Heilig and others, 2010; Mitterer and others, 2011a; Singh and others, 2011; Schmid and others, 2014), have been acquired using GPR from ground and airborne platforms. Furthermore, GPR can profile a large area in a short time. However, the accuracy of the GPR measurements depends upon the dielectric constant of the medium under investigation. The dielectric properties are also important in the estimation of snow wetness, density, emissivity, albedo, etc. from various satellite data (Armstrong, 1976; Warren and Wiscombe, 1985; Conway and Raymond, 1993; Gupta and others, 2005).

Previous studies include laboratory and field-based investigations of snow dielectric properties using different experimental set-ups (Polder and Van Santen, 1946; Taylor, 1965; Tiuri and others, 1984; Hallikainen and others, 1986; Denoth, 1989; Kovacs and others, 1995; Mätzler, 1996). Further, these studies have reported that a good relationship exists between the dielectric constant $\varepsilon^{\prime}$ (the real part of the relative permittivity) and snow density. However, in Antarctica, due to more porous and complex snow structure, the relationship between dielectric constant $\left(\varepsilon^{\prime}\right)$ and snow density was observed to be poor (Shiraiwa and others, 1996; Kärkäs and others, 2005). The dielectric properties of snow also depend on snow structure, grain arrangement and state of metamorphism. Colbeck (1982) discussed the effect of different types of snow structure on dielectric properties. Recently, Sugiyama and others (2010) performed several measurements to observe the effect of snow-grain bonding on the dielectric properties of Antarctic snow.

The presence of liquid water in snow significantly affects its dielectric properties. Therefore, investigation of the dielectric properties of wet snow is always difficult and challenging compared with dry snow. Wiesinger and others (2013) investigated dielectric properties and liquid-water content (LWC) of wet snow using a combination of GPR and moisture sensors. Heterogeneous meltwater percolation within the layered snowpack poses several problems/ limitations in field measurements of dielectric properties. The presence of ice layers or lenses in the snow leads to localized ponding (Colbeck, 1978), which can influence the dielectric properties.

Radio-echo sounding and satellite remote sensing are tools being investigated for the study of snow and ice in the Himalaya (Kulkarni and others, 2010; Singh and others, 2010, 2012). However, only a few studies have reported dielectric properties obtained from satellite data and ground measurements (Singh and others, 2011; Thakur and others, 


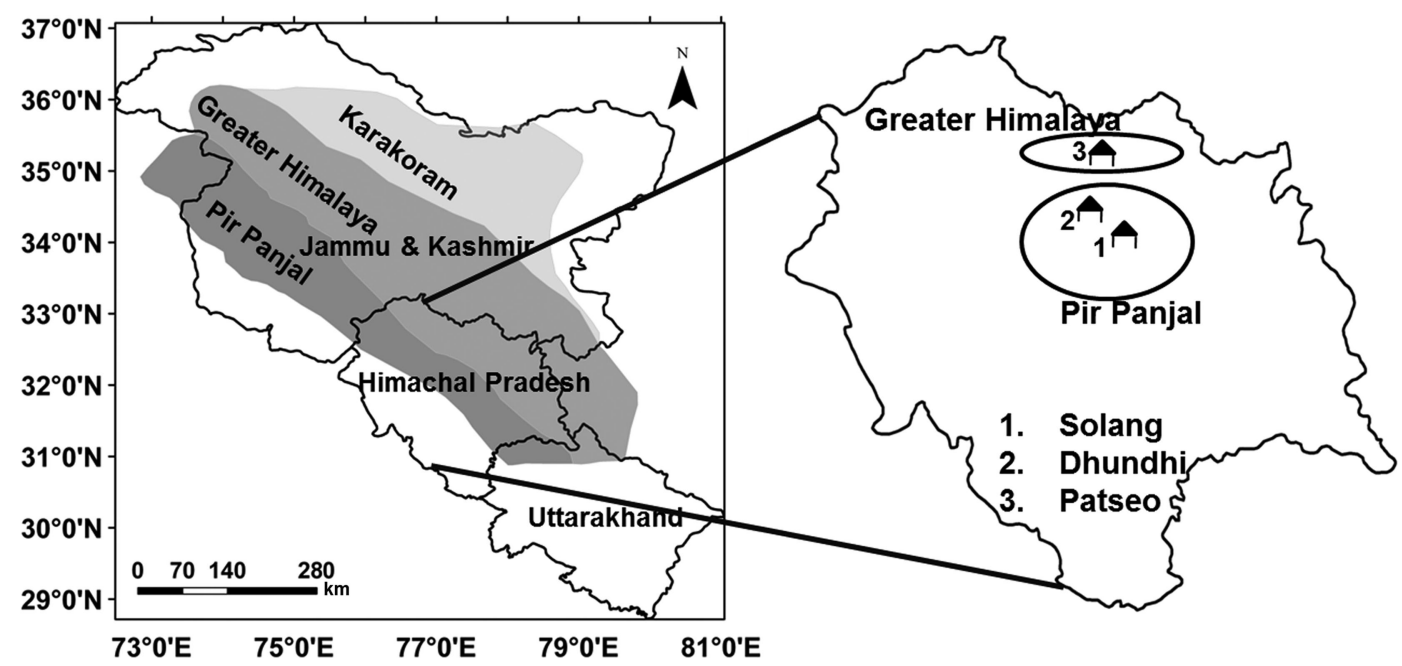

Fig. 1. Map showing locations in Himachal Pradesh, India, where snow fork measurements were conducted.

2012). In one of these studies, Singh and others (2011) measured the dielectric properties of a layered snowpack in dry and wet conditions for a short time span at two climatically different field locations in the Indian Himalaya.

In the present study, we report measurements and analysis of snow dielectric properties carried out at three locations in the northwest Himalaya. Data were collected during the winter in 2010-14 using a 'snow fork' instrument. Snowpack properties, such as density, LWC and snow temperature, were also measured. Extensive data analysis was carried out to observe the interseasonal variation of snow dielectric constant, and a relation was obtained between dielectric constant and LWC for different density classes of snow. This study also adds a snow dielectric constant database for different snow densities and grain morphologies of Himalayan snow. The seasonal dielectric properties over many years may provide representative dielectric constants for radio-echo sounding applications. The interseasonal variation in dielectric properties may
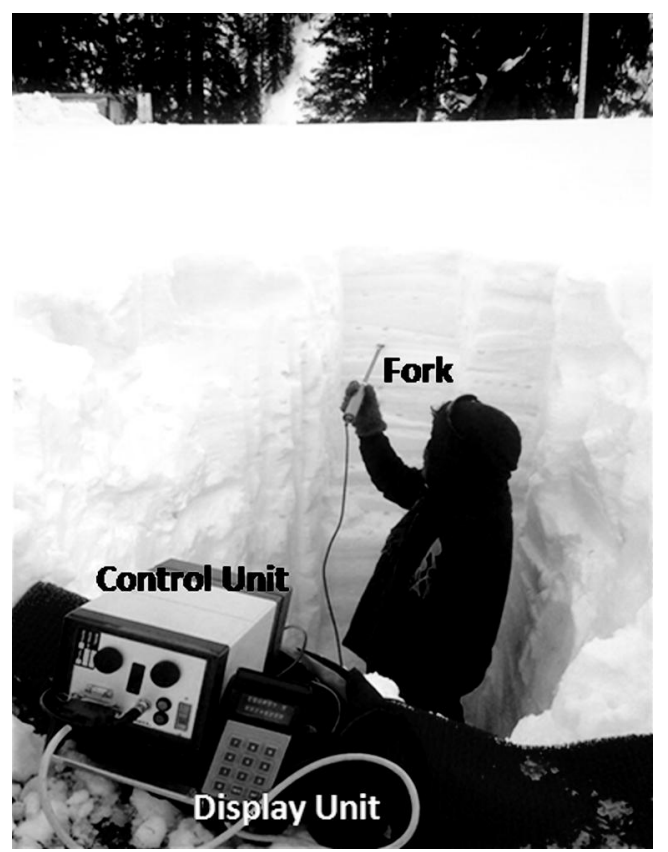

Fig. 2. Photograph of snow fork instrument during data collection. serve as an indicator of snowmelt patterns over time. Furthermore, these data and the analysis may help to predict the state of the snowpack in terms of wetness and density and their spatial and temporal variability.

\section{STUDY AREA}

Experiments were conducted at three different locations in the northwest Himalaya: two in the Pir Panjal range and one in the Greater Himalayan range (Fig. 1). In the Pir Panjal range, dielectric constant data were collected at Snow and Avalanche Study Establishment (SASE) snow meteorological observatories at Dhundhi $\left(32^{\circ} 21^{\prime} 19.5^{\prime \prime} \mathrm{N}, 77^{\circ} 07^{\prime} 42^{\prime \prime} \mathrm{E}\right.$; 3050 m a.s.l.) and Solang (32 $19^{\prime} 32.42^{\prime \prime} N$, $77^{\circ} 09^{\prime} 29.16^{\prime \prime} \mathrm{E}$; 2480 ma.s.l.). Dhundhi experiences a maritime climate, with heavy snowfall and mild temperatures leading to an isothermal and moist snowpack. The mean wintertime air temperature in the Dhundhi region over the past 19 years has varied between $-1.5^{\circ} \mathrm{C}$ and $2.8^{\circ} \mathrm{C}$, and wintertime snowfall in this area ranges from 255 to $1186 \mathrm{~cm}$, with an average of $817 \mathrm{~cm}$ (Gusain and others, 2009). Solang is located at a lower altitude than Dhundhi and it experiences medium snowfall with relatively high temperatures. The other experimental site, Patseo $\left(32^{\circ} 45^{\prime} 18^{\prime \prime} \mathrm{N}, 77^{\circ} 15^{\prime} 43^{\prime \prime} \mathrm{E}\right.$; $3800 \mathrm{~m}$ a.s.I.), lies in the Greater Himalayan range. This area experiences high wind, lower snowfall and lower temperatures compared with the Pir Panjal range. In this region, slopes are rocky and mostly barren, with sparse vegetation. The mean seasonal air temperature and snowfall in this region have varied over the past 22 years from $-5.9^{\circ} \mathrm{C}$ to $-10.7^{\circ} \mathrm{C}$ and 134 to $410 \mathrm{~cm}$ respectively.

\section{INSTRUMENT AND METHODOLOGY}

In each of the field experiments, a snow pit was dug to carry out dielectric and stratigraphic measurements.

\subsection{Dielectric measurements using snow fork}

The experimental set-up used for dielectric measurements in the field is shown in Figure 2. The snow fork consists of a two-armed steel wave-guide (fork) as a microwave resonator, a control unit and display. It operates at $1 \mathrm{GHz}$ frequency and measures electrical variables such as resonant frequency and attenuation with $3 \mathrm{~dB}$ bandwidth 
for estimating complex permittivity (Sihvola and Tiuri, 1986). The real and imaginary components of the permittivity are estimated using the resonance frequency variation in air and snow:

$$
\begin{gathered}
\varepsilon^{\prime}=\left(f_{\text {air }} / f_{\text {snow }}\right)^{2} \\
\varepsilon^{\prime \prime}=\left(B-B_{d}\right) /\left(f_{\text {snow }} \varepsilon^{\prime}\right)
\end{gathered}
$$

where $\varepsilon^{\prime}$ is the relative permittivity (real part), $\varepsilon^{\prime \prime}$ is the relative permittivity (imaginary part), $f_{\text {snow }}$ is the resonant frequency in snow, $f_{\text {air }}$ is the resonant frequency in air, $B$ is the bandwidth in air and $B_{d}$ is the bandwidth in snow $\left(B_{d}=0.04\left(f_{\text {snow }}-400\right)\right)$. The average permittivity obtained using the snow fork represents a snow sample of effective length $\sim 6 \mathrm{~cm}$ and diameter $\sim 2 \mathrm{~cm}$ (Tiuri and others, 1984; Toikka Engineering Ltd, 2010). LWC and snow density are calculated as follows:

$$
\begin{gathered}
W_{\text {vol }}=-0.06+\sqrt{(0.06)^{2}+\varepsilon^{\prime \prime} /\left(0.0075 f_{\text {snow }}\right)} \\
\rho=-1.214 \\
+\sqrt{(1.214)^{2}-\left(1+8.7 W_{\text {vol }}+70 W_{\text {vol }}^{2}-\varepsilon^{\prime}\right) / 0.7}+W_{\text {vol }}
\end{gathered}
$$

where $W_{\mathrm{vol}}$ is the LWC by volume and $\rho$ is the density of snow $\left(\mathrm{g} \mathrm{cm}^{-3}\right)$.

Before taking dielectric measurements in snow, the snow fork was calibrated in air. The mean resonant frequency in air was found to be $889.4 \mathrm{MHz}$ with standard deviation $\pm 2.6 \mathrm{MHz}$, which is acceptable for accurate dielectric measurements (Toikka Engineering Ltd, 2010). At all field locations the calibration process was repeated before each set of measurements. The probe of the snow fork was inserted in the walls of snow pits horizontally at $10 \mathrm{~cm}$ depth intervals from the bottom to the top surface. The shaded wall of the pit was chosen for the measurements to avoid direct solar radiation heating of the metallic wave guides (Colbeck, 1979; Fierz and Föhn, 1994). The probes were wiped before each insertion to remove attached water and snow.

\subsection{Denoth's relation for snow dielectric estimation}

An empirical relation between relative permittivity, density and LWC proposed by Denoth (1994) was used for the validation and comparison of the snow fork measurements:

$$
\varepsilon^{\prime}=1+1.92 \rho+0.44 \rho^{2}+0.187 W_{\text {vol }}+0.0045 W_{\text {vol }}^{2}
$$

This relation was obtained from measurements with capacitive sensors consisting of two thin conducting strips and operating at a fixed frequency of $20 \mathrm{MHz}$.

\subsection{Snow pit observations}

Different layers in the snowpack were identified to record thickness, temperature, wetness, density, shear strength and hardness (Fierz and others, 2009). In addition, the snow density and temperature were measured every $10 \mathrm{~cm}$ to compare with the snow fork data. The shape and size of the snow grains were determined using a crystal card and magnifying glass. Snow hardness (ram resistance) was measured using a standard Swiss rammsonde (McClung and Schaerer, 1993). The ram resistance is obtained by measuring the vertical penetration of a metallic cone into the snowpack using a weighted hammer on a rule guide rod:

$$
R=\left(\frac{n H I}{p}\right)+T+H
$$
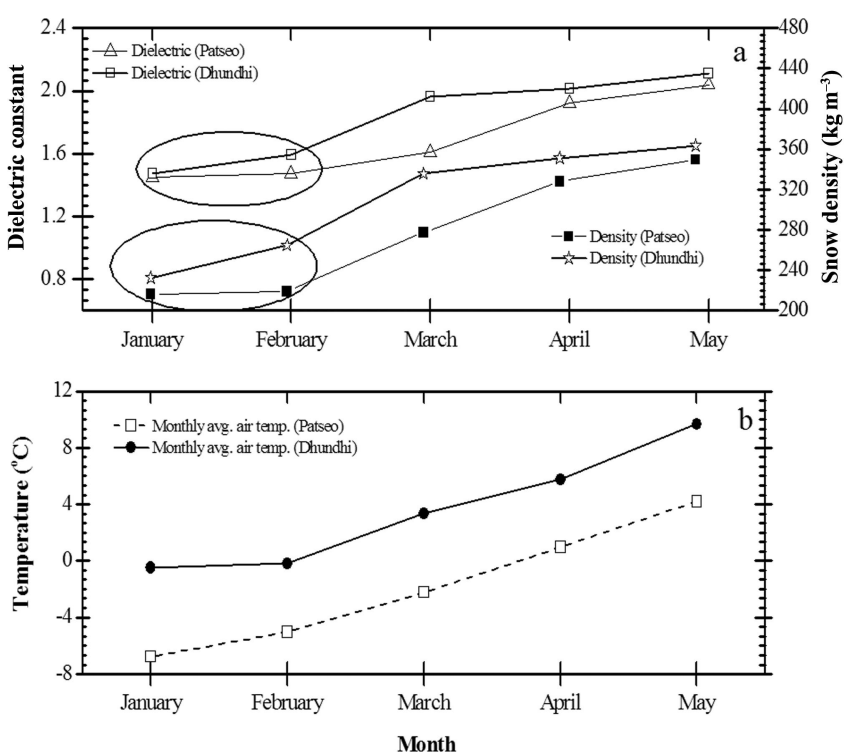

Fig. 3. (a) Temporal variation of monthly averaged dielectric constant and density of snowpack in Dhundhi and Patseo (201014). (b) Monthly averaged air temperature for Dhundhi and Patseo (2010-14).

where $n$ is the number of blows, I is the vertical fall height of the hammer, $H$ is the weight of the hammer and guide rod, $p$ is the penetration depth and $T$ is the total weight of the ram penetrometer tubes applied.

\section{RESULTS}

\subsection{Variation of snowpack dielectric constant and density}

The temporal and spatial variation of dielectric properties and density measured with the snow fork at Dhundhi and Patseo are shown in Figure 3a. Snow dielectric values and density in Dhundhi were observed to be higher than at Patseo. The mean values of seasonal dielectric constant for the study period (2010-14) were $1.69 \pm 0.02$ and $1.82 \pm 0.02$ at Patseo and Dhundhi respectively. The variations in snow density also followed a similar trend. The measured seasonal average density of snowpack was 280 and $310 \mathrm{~kg} \mathrm{~m}^{-3}$ for Patseo and Dhundhi regions, respectively. It was observed that the rate of increase in snowpack dielectric constant and density was higher from January to February at Dhundhi compared with Patseo. This indicates the onset of peak winter melting in Dhundhi, which was not observed in the Patseo region, and is supported by the monthly average air temperature (measured at $\sim 1.2 \mathrm{~m}$ above the surface) as shown in Figure 3b. For Patseo, the rate of increase in snow dielectric constant was observed to be higher from March to April (Fig. 3a), which also follows the temperature trend at Patseo.

During field experiments at Patseo and Dhundhi, we collected snow fork measurements of different types of snow grain (depth hoar $(\mathrm{DH})$, faceted $(\mathrm{FC})$, rounded (RG), precipitation particles (PP), decomposed/fragmented (DF) particles and melt forms (MF)) as presented in Tables 1 and 2. The snow dielectric constant, density and LWC were lowest for precipitation particles $\left(1.21,100 \mathrm{~kg} \mathrm{~m}^{-3}, 0.15 \%\right)$ and highest for faceted snow crystals $\left(1.44,190 \mathrm{~kg} \mathrm{~m}^{-3}, 5.35 \%\right)$. Owing to high temperature and fast metamorphism, mostly rounded 


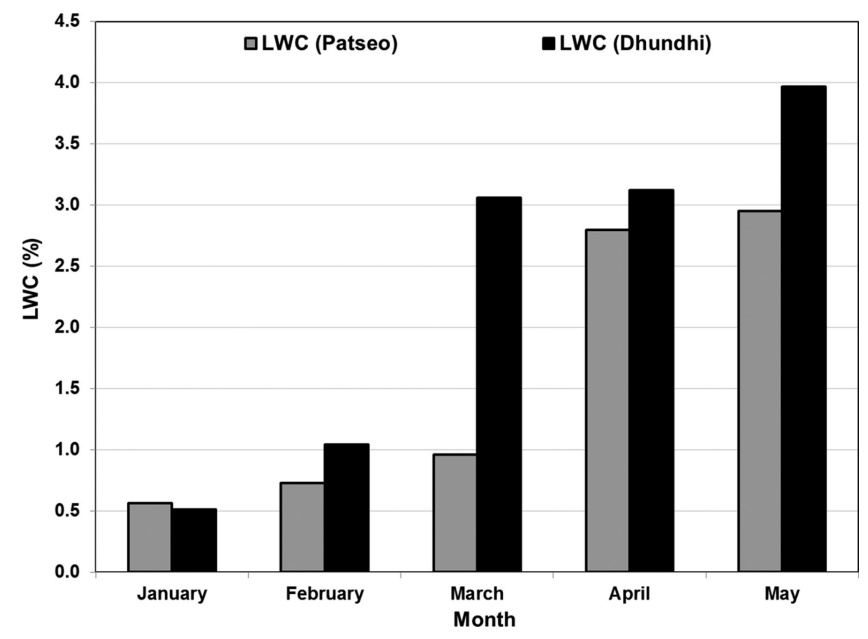

Fig. 4. Monthly variation of average LWC of snowpack in Dhundhi and Patseo (2010-14).

grains and melt forms were observed at Dhundhi. Further, the common snow grains (rounded and MF) found at both locations were analysed. It was observed that the dielectric constant, density and LWC were higher at Dhundhi than at Patseo. For dry snow of density $\sim 260 \mathrm{~kg} \mathrm{~m}^{-3}$ at Patseo, the dielectric constant was found to be highest for rounded grains and lowest for decomposed snow grains (Table 3 ).

\subsection{Variation of snowpack LWC}

LWC significantly affects snow dielectric properties and hence the propagation of radio waves in the snowpack. Figure 4 shows the mean seasonal (2010-14) variation of LWC for Dhundhi and Patseo. The mean seasonal LWC was $1.60 \%$ and $2.39 \%$ for Patseo and Dhundhi respectively. The high value of LWC for the Dhundhi snowpack is mainly attributable to a warm and therefore moist snowpack. It can also be observed from Figure 4 that the maximum change in

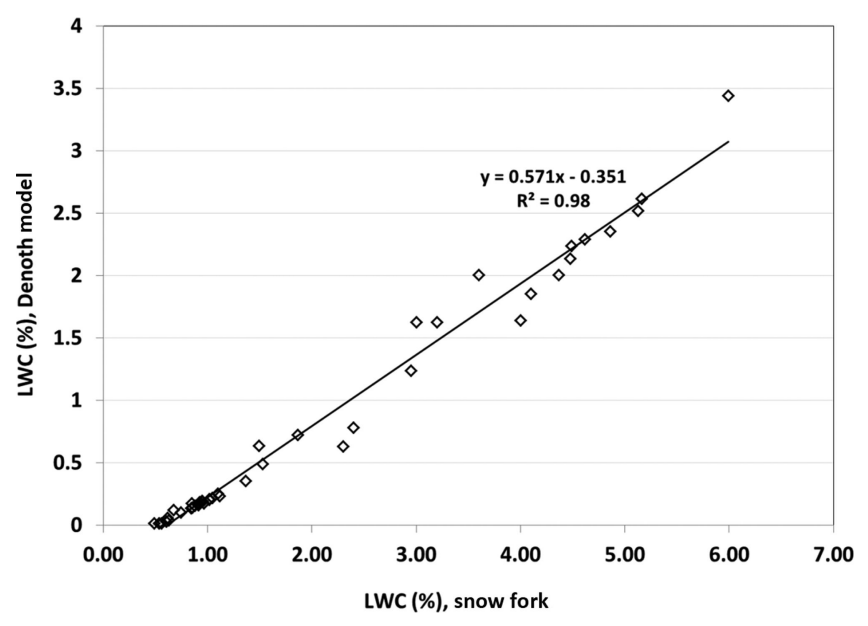

Fig. 5. Comparison between LWC measured by snow fork and estimated by theoretical model (Denoth, 1994).

LWC for Dhundhi was observed between February and March. However, for Patseo such change was observed between March and April. A large difference was found in mean monthly LWC for March compared with the remaining winter months at two field locations. Figure 5 shows a comparison between snow fork LWC and Denoth LWC for Patseo station. A similar trend and very high correlation was found between the LWC values obtained using both methods. However, the LWC values calculated using the Denoth model (mean 0.85) are lower than the snow-forkderived values (mean 2.10).

\subsection{Variation of snowpack dielectric constant with LWC}

To study the effect of LWC on the dielectric constant of the snowpack, the complete database for Dhundhi was grouped into four density classes (Fig. 6a-d). The analysis shows an

Table 1. Average values of dielectric constant, density and LWC for different types of snow grains at Patseo during the study period (2010-14)

\begin{tabular}{|c|c|c|c|c|c|c|c|c|c|c|}
\hline \multirow{2}{*}{$\begin{array}{l}\text { Patseo (Greater Himalaya) } \\
\text { Snow grain type }\end{array}$} & \multirow[b]{2}{*}{ Abbrev. } & \multicolumn{3}{|c|}{ Dielectric constant } & \multicolumn{3}{|c|}{ Density (snow fork) } & \multicolumn{3}{|c|}{ LWC } \\
\hline & & Min. & Max. & Avg. & $\begin{array}{l}\text { Min. } \\
\mathrm{kg} \mathrm{m}^{-3}\end{array}$ & $\begin{array}{l}\text { Max. } \\
\mathrm{kg} \mathrm{m}^{-3}\end{array}$ & $\begin{array}{c}\text { Avg. } \\
\mathrm{kg} \mathrm{m}^{-3}\end{array}$ & $\begin{array}{c}\text { Min. } \\
\%\end{array}$ & $\begin{array}{c}\text { Max. } \\
\%\end{array}$ & $\begin{array}{c}\text { Avg. } \\
\%\end{array}$ \\
\hline Depth hoar & $\mathrm{DH}$ & 1.36 & 1.89 & 1.57 & 160 & 360 & 250 & 0.25 & 3.23 & 1.09 \\
\hline Faceted & $\mathrm{FC}$ & 1.44 & 2.31 & 1.66 & 190 & 350 & 290 & 0.60 & 5.35 & 1.28 \\
\hline Precipitation particles & PP & 1.21 & 1.48 & 1.27 & 100 & 220 & 130 & 0.15 & 0.83 & 0.34 \\
\hline Decomposed/fragmented & DF & 1.30 & 1.60 & 1.42 & 140 & 280 & 190 & 0.45 & 1.26 & 0.76 \\
\hline Melt forms & MF & 1.30 & 1.99 & 1.56 & 140 & 360 & 260 & 0.11 & 3.15 & 0.85 \\
\hline
\end{tabular}

Table 2. Average values of dielectric constant, density and LWC for different types of snow grain at Dhundhi (2010-14)

\begin{tabular}{|c|c|c|c|c|c|c|c|c|c|c|}
\hline \multirow{2}{*}{$\begin{array}{l}\text { Dhundhi (Pir Panjal) } \\
\text { Snow grain type }\end{array}$} & \multirow[b]{2}{*}{ Abbrev. } & \multicolumn{3}{|c|}{ Dielectric constant } & \multicolumn{3}{|c|}{ Density (snow fork) } & \multicolumn{3}{|c|}{ LWC } \\
\hline & & Min. & Max. & Avg. & $\begin{array}{l}\text { Min. } \\
\mathrm{kg} \mathrm{m}^{-3}\end{array}$ & $\begin{array}{l}\text { Max. } \\
\mathrm{kg} \mathrm{m}^{-3}\end{array}$ & $\begin{array}{l}\text { Avg. } \\
\mathrm{kg} \mathrm{m}^{-3}\end{array}$ & $\begin{array}{l}\text { Min. } \\
\%\end{array}$ & $\begin{array}{c}\text { Max. } \\
\%\end{array}$ & $\begin{array}{c}\text { Avg. } \\
\%\end{array}$ \\
\hline Rounded & RG & 1.44 & 2.30 & 1.73 & 200 & 420 & 310 & 0.22 & 5.73 & 1.61 \\
\hline Melt forms & MF & 1.37 & 2.80 & 1.87 & 210 & 400 & 320 & 0.15 & 8.79 & 2.71 \\
\hline
\end{tabular}



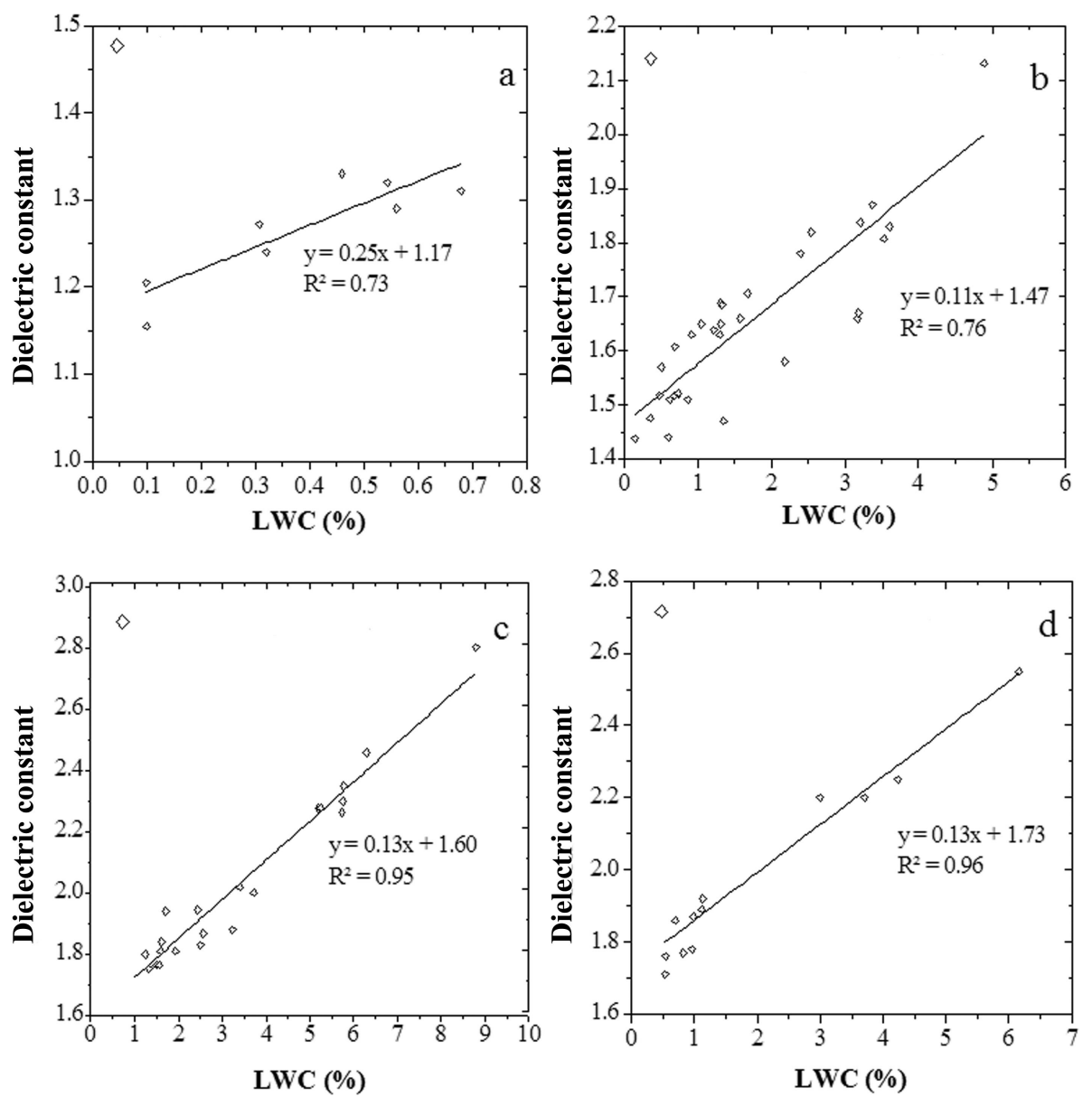

Fig. 6. Variation of dielectric constant of snowpack with its LWC at Dhundhi for different snow density classes: (a) 100-200, (b) 200-300, (c) 300-400 and (d) $>400 \mathrm{~kg} \mathrm{~m}^{-3}$.

increase in snowpack dielectric constant with LWC for each density range. The correlation between dielectric constant and LWC for high-density snow $\left(>300 \mathrm{~kg} \mathrm{~m}^{-3}\right)$ is observed to be higher $\left(R^{2}=0.95\right)$ in comparison with low-density snow $\left(<200 \mathrm{~kg} \mathrm{~m}^{-3}\right)$. A similar analysis to observe the effect of LWC on dielectric constant for Patseo could not be carried out as the snowpack in this region remains dry most of the time. Hence, the variation in dielectric constant is mainly due to density.

\subsection{Density comparison: snow fork vs manual measurements}

Comparisons between manually measured and snow-forkestimated snowpack densities are shown in Figure $7 \mathrm{a}$ and $\mathrm{b}$ for Patseo and Dhundhi respectively. The densities obtained using both methods were found to vary from 100 to $400 \mathrm{~kg} \mathrm{~m}^{-3}$ for Patseo and 200 to $430 \mathrm{~kg} \mathrm{~m}^{-3}$ for Dhundhi. It was found that the snow fork could estimate snowpack densities well for Patseo compared with Dhundhi. Large deviations between snow fork and manual densities at Dhundhi may be due to the wetter snowpack. Datt and others (2008) reported large differences in manual density measurements of wet snow.

\subsection{Diurnal variation of snowpack dielectric constant and LWC in different Himalayan ranges}

To study the diurnal variation of snowpack dielectric constant and LWC, snow fork measurements were made simultaneously at three field locations (Patseo, Dhundhi and
Solang) on 18 February 2014. The dielectric constant was higher at Solang than at Dhundhi and Patseo (Fig. 8). The maximum difference in dielectric constant is observed at 14:00 LT (local time; 0830 UTC (coordinated universal time)) and minimum at 17:00 LT (1130 UTC). The diurnal variation in snowpack dielectric constant is observed to be small at Patseo, comparatively large at Dhundhi and very large at Solang.

Figure 9 represents an intercomparison of the diurnal variation of LWC at Patseo, Dhundhi and Solang. The LWC in Solang snowpack is higher than at Dhundhi and Patseo. At Patseo and Dhundhi the LWC is almost constant after 15:00 LT (0930 UTC); however, at Solang the LWC continued to vary until 17:00 LT (1130 UTC).

Snow fork measurements were supported by simultaneous collection of meteorological data using automatic weather stations (AWS). Figure 10 shows the diurnal variation of snow albedo and average air temperature at Solang, Dhundhi and

Table 3. Average values of dielectric constant for different snow grain types (snow density $260 \mathrm{~kg} \mathrm{~m}^{-3}$; LWC $<1 \%$; Patseo station)

\begin{tabular}{lcccc}
\hline $\begin{array}{l}\text { Snow grain } \\
\text { type }\end{array}$ & $\begin{array}{c}\text { Rounded } \\
\text { grains }\end{array}$ & Melt forms & $\begin{array}{c}\text { Depth hoar } \\
\text { Decomposed/ } \\
\text { fragmented }\end{array}$ \\
\hline $\begin{array}{l}\text { Dielectric } \\
\text { constant }\end{array}$ & 1.58 & 1.56 & 1.54 & 1.53 \\
\hline
\end{tabular}



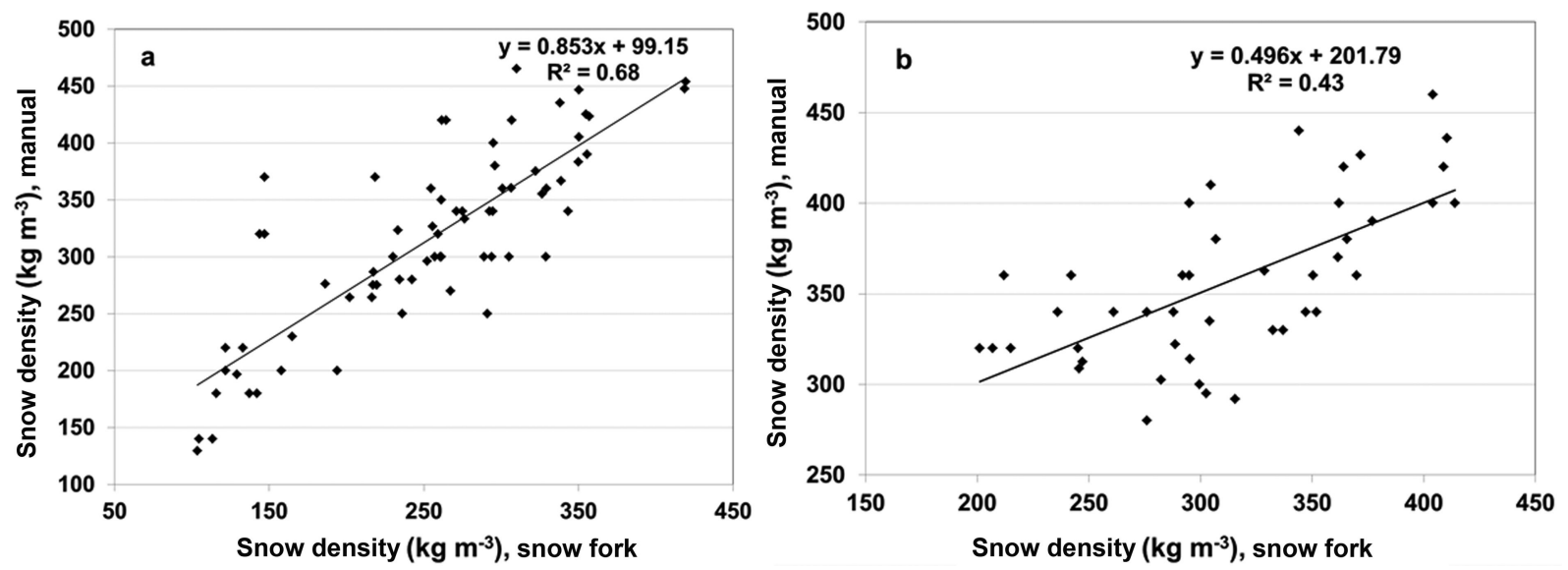

Fig. 7. Comparison between manual and snow fork measured snowpack densities: (a) Patseo and (b) Dhundhi.

Patseo. The air temperature at Patseo was $<0^{\circ} \mathrm{C}$ throughout the observation period; however, at Dhundhi and Solang the temperature was positive. The temperature at Solang was comparatively much higher. The albedo (ratio of outgoing to incoming shortwave radiation) values for snow were observed to be lowest for Solang and highest for Patseo for most of the time. The lower albedo of snow at Solang indicates higher absorption of energy, and thus larger LWC.

The snowpack stratigraphic information for Patseo, Dhundhi and Solang regions for 18 February 2014 is shown in Figure $11 \mathrm{a}, \mathrm{b}$ and $\mathrm{c}$ respectively. The stratigraphy includes the data of various attributes, i.e. layer thickness, snow grain type, grain size and snow density of different layers in the snowpack. Ram resistance shows the resistance of snow at different depths. The snow temperature was also measured every $10 \mathrm{~cm}$ (Fig. 11a-c). The snowpack at Solang and Dhundhi was close to isothermal at $\sim 0^{\circ} \mathrm{C}$. However, for Patseo, the snowpack was well below freezing. The high average air and snowpack temperatures and low snow albedo at Solang and Dhundhi are mainly responsible for the higher snow dielectric constant and LWC.

\section{DISCUSSION}

In this study we conducted snow dielectric constant and LWC measurements using a snow fork at different locations in the northwest Indian Himalaya. Owing to the thick

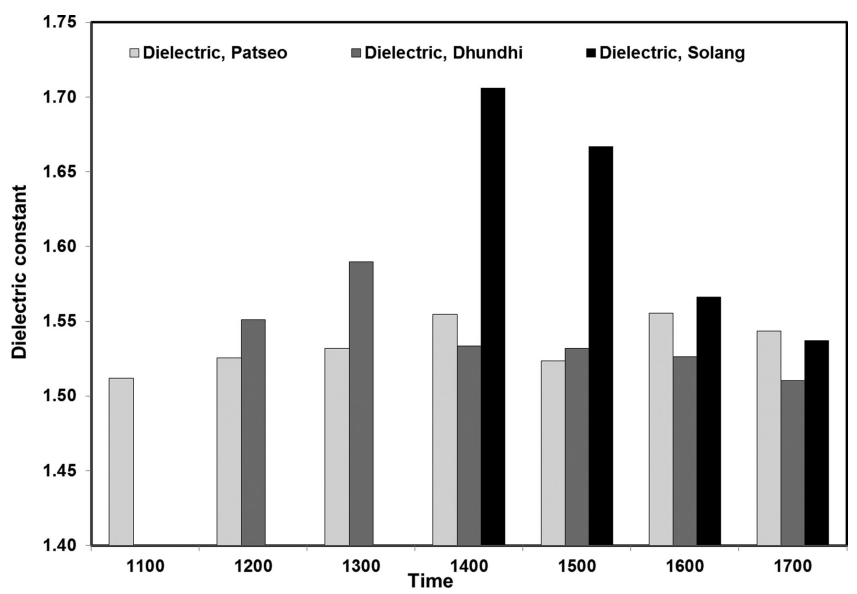

Fig. 8. Diurnal variation of dielectric constant of snowpack at Patseo, Dhundhi and Solang on 18 February 2014. snowpack and mild air temperatures, the snowpack at Dhundhi remains moist and mainly consists of equitemperature-type snow grains in early and mid-winter. The average snowpack temperature gradients reported are $2-15^{\circ} \mathrm{C} \mathrm{m}^{-1}$ for mid-winter and $0-5^{\circ} \mathrm{C} \mathrm{m}^{-1}$ for late winter (Gusain and others, 2004). Snow pit observations at Dhundhi show high density and rounded grains throughout the snowpack (Fig. 11b).

The snowpack at Patseo remains dry and shallow, with mostly temperature-gradient snow grains (depth hoar) in early and mid-winter. During late winter (March onwards), melt-freeze snow grains were also observed. The temperature gradient for a typical profile during this study was $10.4^{\circ} \mathrm{C} \mathrm{m}^{-1}$ (Fig. 11a). Gusain and others (2004) reported an average snowpack temperature gradient of $10-62^{\circ} \mathrm{C} \mathrm{m}^{-1}$ for mid-winter and $5-25^{\circ} \mathrm{C} \mathrm{m}^{-1}$ for late winter at Patseo.

The dielectric constant of snow depends on various properties (e.g. ice fraction, LWC, crystal fabric). The value of dielectric constant is much higher for water $(\sim 86)$ than for air $(\sim 1)$ and ice ( 3.15) (Louge and others, 1998). Therefore, a small amount of water changes the dielectric properties of snow significantly (Schmid and others, 2014). The dielectric measurements during this study cover pre-, mid- and late winter, ranging from January to May. As discussed in Section 4, the air temperature at Patseo was below $0^{\circ} \mathrm{C}$ until March. Consequently, the snowpack was dry and variations in dielectric properties are mainly

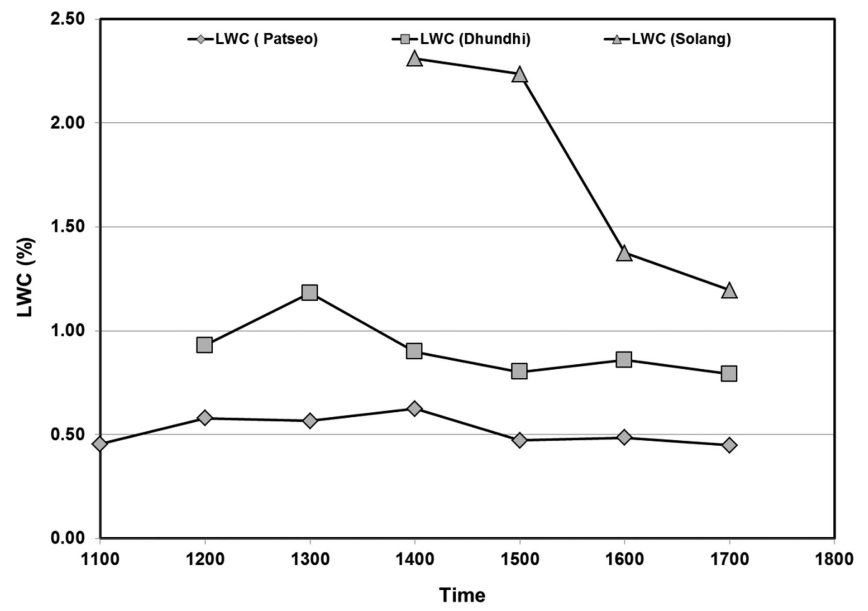

Fig. 9. Diurnal variation of water content in snowpack at Patseo, Dhundhi and Solang on 18 February 2014. 


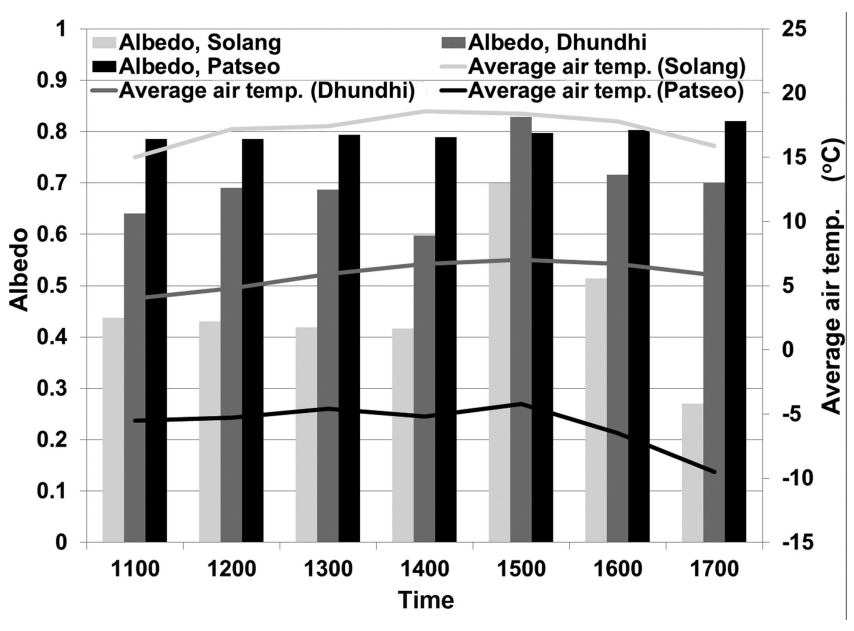

Fig. 10. Diurnal variation of air temperature and albedo at Patseo, Dhundhi and Solang on 18 February 2014.

attributed to density changes (Frolov and Macheret, 1999). Contrary to this, the variations in dielectric constant values for the Dhundhi snowpack are due to the combined effect of density variation and the presence of LWC.

It is interesting to note a lag of $\sim 1$ month in the evolution of the dielectric constant for Patseo in comparison with Dhundhi (Fig. 3a). There is a significant increase in dielectric constant from February to March for Dhundhi and March to April for Patseo. A change of $\sim 0.31$ and $\sim 0.37$ in snow dielectric constant was observed for Patseo and Dhundhi, respectively. The variations in snow dielectric constant follow the density and LWC as also reported in previous studies (Frolov and Macheret, 1999).

Apart from ice volume fraction, the dielectric constant of snow also depends on the structural arrangement of ice particles. The structural dependence of snow dielectric constant has been discussed in several studies (Colbeck, 1982; Denoth, 1982; Sihvola and others, 1985; Kovacs and others, 1995). However, to the best of our knowledge, there exist only a few dielectric field measurements corresponding to different types of snow grain (Sugiyama and others, 2010). Part of this study aimed to observe the effect of snow grain size on dielectric constant values. A dataset of dielectric constant measured at comparable density $\left(\sim 260 \mathrm{~kg} \mathrm{~m}^{-3}\right)$ and LWC $(\sim<1 \%)$ was selected for different snow types. It was observed that the dielectric constant was greatest for RG grains, followed by MF, DH and DF. These observations are in agreement with experimental values previously reported (Sugiyama and others, 2010) and also with mixture theory (Polder and Van Santen, 1946).

The LWC of a snow cover plays an important role in latewinter avalanche hazard prediction (Techel and Pielmeier, 2011), snow hydrology (Frolov and Macharet, 1999), etc. However, the dynamic and stratified nature of the snowpack makes in situ measurements of LWC difficult. The snow fork has an advantage for LWC measurements over other methods used by past researchers (Stein and others, 1997) as it offers portability and fast data collection. As discussed previously, the snowpack at Dhundhi evolves under mild temperatures, which results in a homogeneous snowpack. However, at Patseo, the snowpack is relatively more stratified due to the presence of several ice/MF layers. At Dhundhi, snowmelt and basal discharge generally begin in March (Datt and others, 2008). During this month the mean
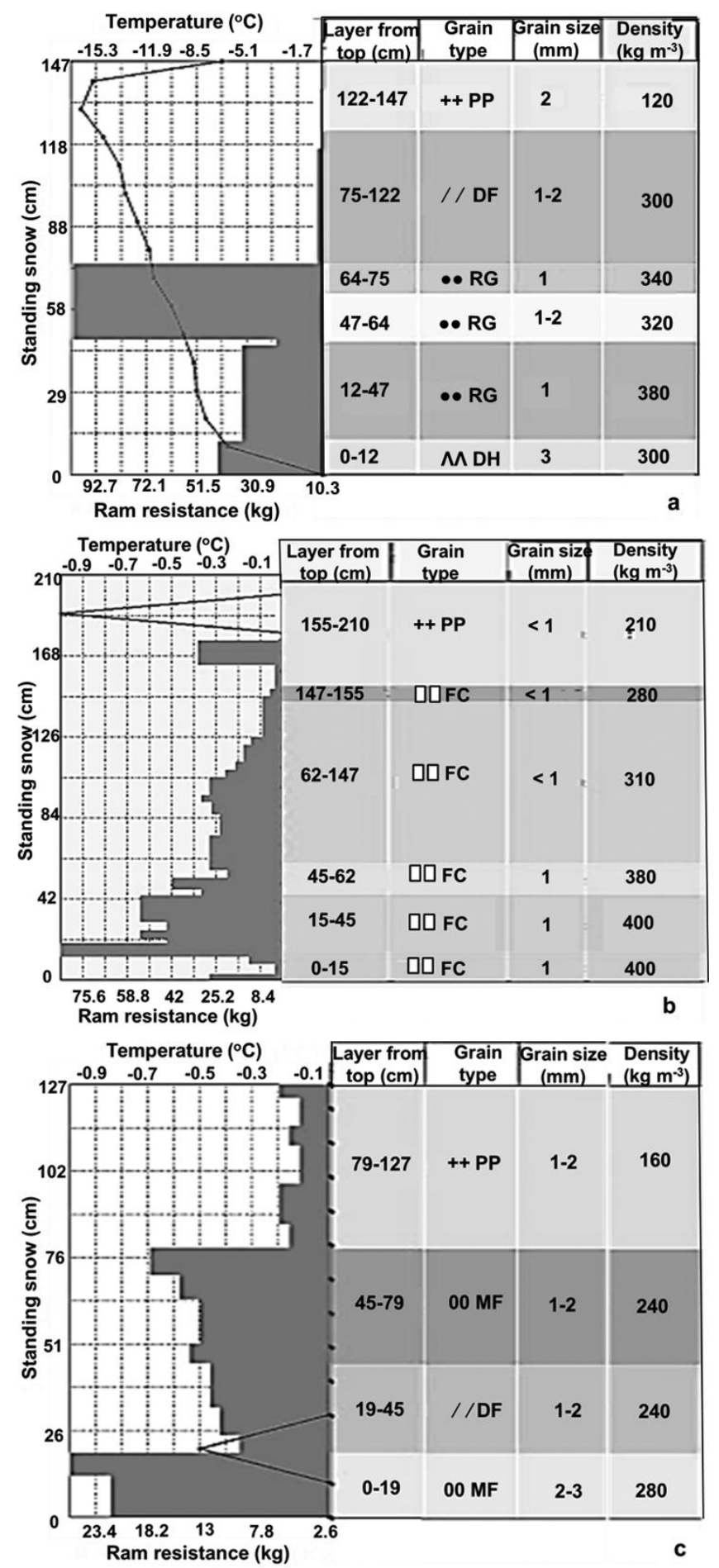

Fig. 11. Snowpack characterization by manual observation on 18 February 2014: (a) Patseo, (b) Dhundhi and (c) Solang. DF: decomposed/fragmented particles; RG: rounded grains; $\mathrm{DH}$ : depth hoar; PP: precipitation particles; FC: faceted crystals; MF: melt forms.

LWC was $\sim 3.1 \%$ for Dhundhi, increasing to $\sim 4 \%$ by May. However, for Patseo the sudden change in LWC was observed in April, with mean $\sim 2.79 \%$, and remained more or less constant until May. Our measured data are predicted well by the empirical relation of Denoth (1994). However, the empirical relation was found to underestimate LWC. Our results support the increase in snow dielectric constant values with LWC as reported in previous studies. Moreover, the increase in dielectric constant values is better correlated with LWC in the case of higher-density snow. 


\section{CONCLUSION}

A database for dielectric properties of the snowpack was prepared using a snow fork at three different field locations in the Indian Himalaya. An analysis was carried out to observe the spatial and temporal variations in snowpack properties, i.e. dielectric constant, density and LWC. Higher dielectric constant values were observed for the Dhundhi snowpack than for the Patseo snowpack. Dielectric constant values corresponding to different snow types are reported. In addition, variation in dielectric properties for different snow types with the same density was analysed. Snow fork LWC was compared with Denoth LWC values and good agreement was observed. Manual pit observations were also made at snow fork measurement sites. A good correlation was observed between snowpack density measured manually and with the snow fork. Relations between dielectric constant and LWC are developed for different snow density classes for the Dhundhi region. The diurnal variation of LWC and dielectric constant for the Solang snowpack is higher than for Dhundhi and Patseo. It is concluded that relatively higher temperatures (air and snowpack) and lower albedo of snow are responsible for the higher dielectric constant and LWC in the Solang region. The dielectric database collected using a snow fork can provide accurate estimation of LWC. Furthermore, it may be used for estimating electromagnetic wave velocity required for GPR measurements for various snow applications. Moreover, the database can also be used to validate snow depth and wetness maps estimated using remote sensing.

\section{ACKNOWLEDGEMENTS}

We thank Ashwagosha Ganju (Director, SASE) for his constant motivation and support, and V.D. Mishra, P.K. Srivastava and Chaman Chandel for technical support during preparation of the manuscript. We also acknowledge the efforts made by Roshan Tamang, Rakesh Ranjan, Ankur Parashar and Ramanand Chauhan in field data collection. The comments of $\mathrm{S}$. Koch and an anonymous referee are acknowledged. We also thank the editors G. Cogley and N. Eckert for their comments, which significantly improved the manuscript.

\section{REFERENCES}

Armstrong R (1976) Wet snow avalanches. In Avalanche release and snow characteristics, San Juan Mountains, Colorado. (INSTAAR Occasional Paper 19) Institute of Arctic and Alpine Research, University of Colorado, Boulder, CO, 67-82

Colbeck SC (1978) The physical aspects of water flow through snow. Adv. Hydrosci., 11, 165-206

Colbeck SC (1979) Water flow through heterogeneous snow. Cold Reg. Sci. Technol., 1, 37-45

Colbeck SC (1982) An overview of seasonal snow metamorphism. Rev. Geophys., 20, 45-61 (doi: 10.1029/RG020i001p00045)

Conway H and Raymond C (1993) Snow stability during rain. J. Glaciol., 39, 635-642

Datt P, Srivastava PK, Negi PS and Satyawali PK (2008) Surface energy balance of seasonal snow cover for snow-melt estimation in N-W Himalaya. J. Earth Syst. Sci., 117, 567-573 (doi: 10.1007/s12040-008-0053-7)

Denoth A (1982) Effect of grain geometry on electrical properties of snow at frequency up to $100 \mathrm{MHz}$. J. Appl. Phys., 53(11), 7496-7501 (doi: 10.1063/1.330157)
Denoth A (1989) Snow dielectric measurements. Adv. Space Res., 9, 233-243 (doi: 10.1016/0273-1177(89)90491-2)

Denoth A (1994) An electronic device for long term snow wetness recording. Ann. Glaciol., 19, 104-106

Fierz C and P. Föhn (1994) Long-term observation of the water content of an Alpine snowpack. In Proceedings of the International Snow Science Workshop, 30 October-3 November 1994. Snowbird, UT, 117-131

Fierz C and 8 others (2009) The international classification for seasonal snow on the ground. (IHP-VII Technical Documents in Hydrology No. 83, IACS Contribution No. 1) UNESCOInternational Hydrological Programme, Paris.

Frolov A and Macharet Y (1999) On dielectric properties of dry and wet snow. Hydrol. Process., 13, 1755-1760 (doi: 10.1002/(SICI) 1099-1085(199909)13:12/13<1755::AID-HYP854>3.0.CO;2-T)

Gupta RP, Haritashya UK and Singh P (2005) Mapping dry/wet snow cover in the Indian Himalayas using IRS multispectral imagery. Remote Sens. Environ., 97(4), 458-469 (doi: 10.1016/ j.rse.2005.05.010)

Gusain HS, Singh A, Ganju A and Singh D (2004) Characteristics of the seasonal snow cover of Pir Panjal and Great Himalayan Ranges in Indian Himalaya. In Proceedings of the International Symposium on Snow Monitoring and Avalanches, 12-16 April 2004. Snow and Avalanche Study Establishment, Manali, 97-102

Gusain, HS, Chand D, Thakur NK, Singh A and Ganju A (2009) Snow avalanche climatology of Indian Western Himalaya. In Proceedings of the International Symposium on Snow and Avalanches, 6-10 April 2009. Snow and Avalanche Study Establishment, Manali, 85-93

Hallikainen M, Ulaby FT and Abdelrazik M (1986) Dielectric properties of snow in the 3 to $37 \mathrm{GHz}$ range. IEEE Trans. Antennas Propag., 34, 1329-1339 (doi: 10.1109/TAP.1986.1143757)

Heilig A, Eisen O and Schneebeli M (2010) Temporal observations of a seasonal snowpack using upward-looking GPR. Hydrol. Process., 24, 3133-3145 (doi: 10.1002/hyp.7749)

Kärkäs E, Martma T and Sonninen E (2005) Physical properties and stratigraphy of surface snow in western Dronning Maud Land, Antarctica. Polar Res., 24, 55-67 (doi: 10.1111/j.1751-8369. 2005.tb00140.x).

Kovacs A, Gow A and Morey R (1995) The in situ dielectric constant of polar firn revisited. Cold Reg. Sci. Technol., 23, 245-256 (doi: 10.1016/0165-232X(94)00016-Q)

Kulkarni AV, Rathore BP, Singh SK and Ajai (2010) Distribution of seasonal snow cover in central and western Himalaya. Ann. Glaciol., 51, 123-128 (doi: 10.3189/172756410791386445)

Louge M, Foster R, Jensen N and Patterson R (1998) A portable capacitance snow sounding instrument. Cold Reg. Sci. Technol. 28, 73-81 (doi: 10.1016/S0165-232X(98)00015-9)

Machguth H, Eisen O, Paul F and Hoelzle M (2006) Strong spatial variability of snow accumulation observed with helicopterborne GPR on two adjacent Alpine glaciers. Geophys. Res. Lett., 33, L13503 (doi: 10.1029/2006GL026576)

Mätzler C (1996) Microwave permittivity of dry snow. IEEE Trans. Geosci. Remote Sens., 34, 573-581 (doi: 10.1109/36.485133)

McClung DM and Schaerer P (1993) The avalanche handbook. The Mountaineers, Seattle, Washington, USA

Mitterer C, Heilig A, Schweizer J and Eisen O (2011a) Upwardlooking ground penetrating radar for measuring wet-snow properties. Cold Reg. Sci. Technol., 69, 129-138 (doi: 10.1016/j.coldregions.2011.06.003)

Polder D and Van Santen JH (1946) The effective permeability of mixtures of solids. Physica, 12(5), 257-271 (doi: 10.1016/ S0031-8914(46)80066-1)

Schmid L and 6 others (2014) Continuous snowpack monitoring using upward-looking ground-penetrating radar technology. J. Glaciol., 60, 509-525 (doi: 10.3189/2014JoG13J084)

Shiraiwa T, Shoji H, Saito T, Yokoyama K and Watanabe O (1996) Structure and dielectric properties of surface snow along the traverse route from coast to Dome Fuji Station, Queen Maud 
Land, Antarctica. Proc. NIPR Symp. Polar Meteorol. Glaciol., 10, $1-12$

Sihvola A and Tiuri M (1986) Snow fork for field determination of the density and wetness profiles of a snow pack. IEEE Trans. Geosci. Remote Sens., 24(5), 717-721 (doi: 10.1109/ TGRS.1986.289619)

Sihvola A, Nyfors E and Tiuri M (1985) Mixing formulae and experimental results for the dielectric constant of snow. J. Glaciol., 31(108), 163-170

Singh KK, Kulkarni AV and Mishra VD (2010) Estimation of glacier depth and moraine cover study using ground penetrating radar (GPR) in the Himalayan region. J. Indian Soc. Remote Sens., 38, 1-9

Singh KK and 6 others (2011) Snow depth and snow layer interface estimation using Ground Penetrating Radar. Curr. Sci., 100, 1532-1539

Singh SK, Rathore BP, Bahuguna IM, Ramnathan AL and Ajai (2012) Estimation of glacier ice thickness using ground-penetrating radar in the Himalayan region. Curr. Sci., 103, 68-73

Stein J, Laberge G and Lévesque D (1997) Measuring the dry density and the liquid water content of snow using time domain reflectometry. Cold Reg. Sci. Technol., 25, 123-136

Sugiyama S, Enomoto H, Fujita S, Fukui K, Nakazawa F and Holmlund P (2010) Dielectric permittivity of snow measured along the route traversed in the Japanese-Swedish Antarctic
Expedition 2007/08. Ann. Glaciol., 51, 9-15 (doi: 10.3189/ 172756410791392745)

Taylor L (1965) Dielectric properties of mixtures. IEEE Trans. Antennas Propag., 6, 943-947 (doi: 10.1109/TAP.1965.1138567)

Techel F and Pielmeier C (2011) Point observations of liquid water content in wet snow: investigating methodical, spatial and temporal aspects. Cryosphere., 5, 405-418 (doi: 10.5194/tc-5405-2011)

Thakur PK and 6 others (2012) Snow physical parameters estimation using space-based synthetic aperture radar. Geocarto Int., 3, 263-288 (doi: 10.1080/10106049.2012.672477)

Tiuri MT, Sihvola AH, Nyfors EG and Hallikainen MT (1984) The complex dielectric constant of snow at microwave frequencies. IEEE J. Ocean. Eng., 9(5), 377-382 (doi: 10.1109/JOE.1984. 1145645)

Toikka Engineering Ltd (2010) Snow fork: a portable instrument for measuring properties of snow (brochure). Toikka Engineering Ltd, Espoo http://www.toikkaoy.com

Warren SG and Wiscombe WJ (1985) Dirty snow after nuclear war. Nature, 313, 467-470 (doi: 10.1038/313467a0)

Wiesinger T, Oberhammer M, Seiwald J and Koch S (2013) Wet snow instabilities - multiple approaches to lift the veil. In Proceedings of the International Snow Science Workshop, 7-11 October 2013, Grenoble, France. ANENA, IRSTEA, MétéoFrance, Grenoble, 920-925 